This is the pre-peer reviewed version of the following article: De Clercq, Dirk, Rahman, Zahid Mohammad and Belausteguigoitia, Imanol (2015) Task conflict and employee creativity : the critical roles of learning orientation and goal congruence. Human Resource Management, which has been published in final form at http://onlinelibrary.wiley.com/doi/10.1002/ hrm.21761/abstract. This article may be used for non-commercial purposes in accordance with Wiley Terms and Conditions for Self-Archiving." 


\title{
Task Conflict and Employee Creativity: The Critical Roles of Learning Orientation and Goal Congruence
}

\author{
Dirk De Clercq ${ }^{1}$ \\ Goodman School of Business \\ Brock University, Canada \\ ddeclercq@brocku.ca
}

\section{Zahid Mohammad Rahman \\ Goodman School of Business \\ Brock University, Canada \\ zahid.rahman@brocku.ca}
Imanol Belausteguigoitia
Instituto Tecnológico Autónomo de México (ITAM)
Mexico City, Mexico
imanol@itam.mx

Paper accepted for Human Resource Management

May 20, 2015

\footnotetext{
${ }^{1}$ Dirk De Clercq is Professor of Management in the Goodman School of Business at Brock University (Canada) and Research Professor in the Small Business Research Centre at Kingston University (UK).
} 


\title{
Task Conflict and Employee Creativity: The Critical Roles of Learning Orientation and Goal Congruence
}

\begin{abstract}
We add to human resource literature by investigating how the contribution of task conflict to employee creativity depends on employees' learning orientation and their goal congruence with organizational peers. We postulate a positive relationship between task conflict and employee creativity and predict that this relationship is augmented by learning orientation but attenuated by goal congruence. We also argue that the mitigating effect of goal congruence is more salient among employees who exhibit a low learning orientation. Our results, captured from employees and their supervisors in a large, Mexican-based organization, confirm these hypotheses. The findings have important implications for HR managers who seek to foster creativity among employees.
\end{abstract}

Keywords: employee creativity, task conflict, learning orientation, goal congruence 


\section{Introduction}

Why are some employees more likely to engage in creative behavior than others? Human resource (HR) researchers and practitioners acknowledge the increasing need for organizations to instill creativity in their employees, to respond to technological changes, competitive pressures, and globalization (Binyamin \& Carmeli, 2010; Wilkens \& London, 2006). Creativity in this sense pertains to the generation of novel and useful ideas for new products, services, or processes (Zhou \& George, 2001), and it enhances employees' job performance and satisfaction (Gilson, Mathieu, Shalley, \& Ruddy, 2005; Kim, Hon, \& Crant, 2009). ${ }^{2}$ Although creativity has a central role in personal and organizational effectiveness, we lack a clear understanding of how such behavior emerges, particularly from knowledge exchanges among employees, which might involve confrontations and conflicting viewpoints (Chen \& Chang, 2005; Farh, Lee, \& Farh, 2010; Hoever, van Knippenberg, van Ginkel, \& Barkema, 2012). Such task conflict might spur novel idea generation, but the pressures and interpersonal animosity that often accompany it also could challenge this process (De Dreu \& Weingart, 2003; Janssen \& Giebels, 2013). For HR managers, it thus is critical to understand the conditions in which task conflict enhances or hinders employee creativity.

We posit that even when opposing viewpoints help employees develop novel ideas, the strength of this beneficial relationship may vary significantly, depending on other factors (Farh et al., 2010). Previous research suggests that the positive relationship between task conflict and general performance outcomes may be less prevalent in the presence of negative side effects, such as cognitive overload (Carnevale \& Probst, 1998; De Dreu \& Weingart, 2003) or destructive relationship dynamics (Janssen \& Giebels, 2013; Simons \& Peters, 2000). In this

\footnotetext{
${ }^{2}$ Although creativity involves both novelty and usefulness, for parsimony, we do not systematically include the term "usefulness" throughout the paper.
} 
study, we predict that the conversion of task conflict into employee creativity depends on the ability of their organizations to overcome employees' reliance on their current knowledge set and adherence to established organizational goals (Leonard-Barton, 1992; Zhou \& George, 2001). To the extent that employees embrace the comfort of their current expertise (Schneider, Goldstein, \& Smith, 1995), they likely fail to recognize the need for change (Gilbert, 2005; Oreg, 2003). This propensity may diminish their ability to evaluate opposing viewpoints and how these viewpoints might be used to improve the current organizational situation (Enz, 1988). Moreover, even when organizations seek to promote creativity, their employees might hesitate to leverage diverging opinions into novel ideas, for fear of undermining the status quo associated with the current organizational goal set (Sutton \& Hargadon, 1996). In particular, employees may expect that their novel ideas will be met with strong resistance from organizational peers, because novel ideas can threaten existing privileges and organizational practices (LePine \& Van Dyne, 1998; Zhou \& George, 2001).

Understanding which circumstances encourage employees to leverage task conflict into greater creativity, despite the presence of these challenges, therefore requires an elaboration of the conditions in which employees become attuned to and act on conflicting viewpoints. Prior research has tended to focus on the performance benefits of task conflict in general (e.g., De Church \& Marks, 2001; Jehn \& Bendersky, 2003; cf. De Dreu, 2006), rather than its conditional effects for the emergence of creative behavior (Farh et al., 2010; Hoever et al., 2012) Thus, HR managers clearly need more insights into when conflicting viewpoints are most likely to contribute to the generation of novel ideas. In most organizations, task conflict is a significant element of employees' daily functioning that they cannot avoid, even if the organization seeks to limit it (De Dreu \& Weingart, 2003; Hoever et al., 2012). For example, to the extent that 
employees' tasks are interdependent (Van der Vegt, Emans, \& van de Vliert, 1999) or they need to compete for limited company resources (Luo, Slotegraaf, \& Pan, 2006), diverging viewpoints about their job tasks likely are inevitable.

Accordingly, we examine the interplay of task conflict with two critical contingencies (learning orientation and goal congruence), as discrete dimensions that underlie employee creativity. Task conflict increases the potential for employee creativity, but the extent to which this potential gets realized depends on employees' propensity to change the current organizational situation (Zhou \& George, 2001), which in turn depends on their learning orientation and goal congruence with organizational peers. Employees' learning orientation speaks to their personal orientation to extend their current knowledge set flexibly and solicit the expertise and skills of others (Dweck, 1986; Wilkins \& London, 2006). It may facilitate the conversion of task conflict into creativity, because it prompts the associated ability to generate novel combinations of divergent knowledge (Button, Mathieu, \& Zajac, 1996). Goal congruence instead captures the extent to which employees believe that they share similar organizational goals with peers (Nahapiet \& Ghoshal, 1998). When such perceptions of goal congruence are high, employees should be more likely to believe that the generation of novel ideas can drastically upset the status quo (Vancouver \& Schmitt, 1991), such that they would expect more organizational resistance to their ideas. ${ }^{3}$

By investigating learning orientation and goal congruence as moderators of the task conflict-employee creativity relationship, we provide important results for HR managers, because these variables offer tools for countering the danger of employees simply adhering to the

\footnotetext{
${ }^{3}$ Although task conflict and goal congruence may capture phenomena that take place at the group level, individual employees who belong to the same group also may have different perceptions of how much task conflict exists in their interactions with colleagues, as well as different perceptions about the level of congruence between their own goals and those of colleagues. Thus, our theoretical arguments center on the direct connection between such individual perceptions and employees' creative behaviors.
} 
status quo during conflict-laden exchanges. A learning orientation is a personal factor that relates to employees' ability to generate novel combinations of personal and peer knowledge (Gong, Huang, \& Farh, 2009). Goal congruence is a contextual factor, associated with the anticipation that novel ideas will not be resisted in the organizational context (Zhou \& George, 2001). Moreover, we acknowledge the interdependency of these personal and contextual factors for the effective application of task conflict. That is, we predict that the inhibiting effect of goal congruence gets mitigated when employees are more learning oriented. The organizational resistance that employees anticipate, due to the presence of a common goal set, thus cannot be considered in isolation from their own capabilities to find novel ways to counter this resistance.

Our proposed theoretical framework, in Figure 1, features the baseline relationship between task conflict and employee creativity, as well as the individual and combined moderating roles of learning orientation and goal congruence.

[Insert Figure 1 about here]

\section{Theoretical Background}

Employee creativity reflects the generation of novel and useful ideas-a critical step that precedes actual idea implementation (Zhou \& George, 2001). To enhance creativity, HR managers might fuel task conflict or disagreements about content-related issues among their employees (Amason, 1996; Jehn, 1995). Previous research suggests several reasons that task conflict may spur the generation of novel ideas. For example, differences in their opinions increase employees' ability to see the contrasting perspectives on an issue and help challenge long-held assumptions (Amason \& Schweiger, 1994; De Dreu \& West, 2001; Simons and Peterson, 2000). Task conflict also diminishes the likelihood that employees exchange redundant information when discussing organizational problems (Hollenbeck, Colquitt, Ilgen, LePine, \& 
Hedlund, 1998), and it motivates employees to find broadly acceptable new solutions to problems (e.g., De Dreu, 2006; De Dreu \& West, 2001). Task conflict thus leads to the emergence of different decision alternatives, better decision quality, and wider acceptance of decisions (Jehn, 1995). Previous research also notes that employees' dissatisfaction can enable the generation of novel ideas to undo the sources of their dissatisfaction (Staw, 1984; Zhou \& George, 2001), so to the extent that conflicting viewpoints are manifestations of dissatisfaction, they should encourage creativity too.

Yet such effective applications of conflicting viewpoints to the generation of novel ideas suffer several challenges. As with any form of conflict, task conflict can prompt negative outcomes, including personal antagonism (De Dreu, 2006; Janssen \& Giebels, 2013). For example, employees might start to focus on the presence of the conflict, rather than on more productive activities such as new idea generation (De Dreu \& Weingart, 2003). We consider two specific challenges to the effective application of task conflict for increasing employee creativity. First, employees may prefer to support their existing investments in familiar knowledge domains, to reap the performance benefits associated with those investments (Christensen \& Bower, 1996). Similarly, they may suffer from cognitive rigidity (Oreg, 2003), such that they rely on their current expertise and knowledge base rather than adapt their skill sets in accordance with changing external circumstances (Leonard-Barton, 1992; Schneider et al., 1995). Second, novel ideas nearly inevitably alter organizational goals and practices, so the generation of such ideas, even if they might be useful for the organization, is risky and likely to prompt significant organizational resistance (Hirschman, 1970; LePine \& Van Dyne, 1998; Zhou \& George, 2001). These two challenges then indicate that the usefulness of task conflict for spurring employee creativity depends on (1) how likely employees are to leave their current comfort zone and infuse 
their current knowledge set with the opposing viewpoints of organizational peers, and (2) whether they anticipate severe opposition to their ideas, due to the presence of a commonly shared organizational goal set. For this study, we represent these two critical factors with the relevant concepts of learning orientation and goal congruence.

A learning orientation reflects employees' propensity to be continuously on the lookout for new knowledge and to exploit that knowledge for personal growth (Dweck \& Leggett, 1988; VandeWalle, Brown, Cron, \& Slocum, 1999). Previous HR management research has suggested that employees' propensity to acquire and apply new knowledge enhances their ability to handle complex work situations, because continuously updating the current knowledge set increases their capacity to cope with uncertainty (Huang, 2012). Similarly, we argue that a learning orientation might facilitate the transformation of conflicting viewpoints into novel combinations of own and peer knowledge. Although previous research points to the importance of a learning orientation for instilling novelty in organizations (Gong et al., 2009; Hirst, van Knippenberg, \& Zhou, 2009), it has not investigated its implications for converting task conflict into employee creativity.

Goal congruence reflects the degree to which employees and their peers adhere to a common organizational goal set (Nahapiet \& Ghoshal, 1998; Vancouver, Millsap, \& Peters, 1994). Research on goal congruence typically addresses its positive outcomes, such as enabling intra-departmental resource exchanges (McDonough, 2000; Tsai \& Ghoshal, 1998) or establishing congruence in perceptions of the value of creativity (e.g., Choi, 2004; Livingstone, Nelson, \& Barr, 1997). Yet little research attention has been devoted to its interplay with task conflict in the generation of employee creativity, particularly in terms of the potentially inhibiting role of goal congruence (Homburg, Krohmer, \& Workman, 1999; Kellermanns, 
Walter, Lechner, \& Floyd, 2012). Specifically, we theorize that goal congruence may have a dysfunctional effect on the application of task conflict to creative outcomes, because it enhances expected organizational resistance to novel ideas and instills complacency (Milliken, Bartel, \& Kurtzberg, 2003), thereby discouraging employees from leveraging different viewpoints to find new courses of action. We also predict that this dysfunctional effect may be less likely among employees who exhibit a strong learning orientation.

\section{Hypotheses}

\section{Task Conflict and Employee Creativity}

Task conflict refers to disagreements about content-related issues, including differences in viewpoints, ideas, and opinions about job tasks (Jehn, 1995). Although task conflict may not be universally beneficial—conflict in any form may generate some discomfort that diminishes collaborative propensities (Kabanoff, 1991)—extant research generally cites the benefits of task conflict in creative settings (Eisenhardt \& Schoonhoven, 1990; Jehn, 1995). For example, task conflict stimulates a greater range of alternative responses to organizational problems (Amason, 1996) and enhances employees' receptivity to the suggested solutions (Jehn, Northcraft, \& Neale, 1999; Pelled, Eisenhardt, \& Xin, 1999). Task conflict also prompts employees to pay more focused attention to how novel ideas might improve their organization's current situation (Ocasio, 1997).

Accordingly, we start by predicting a positive relationship between task conflict and employee creativity. Decisions in settings characterized by task conflict are more original (Van Dyne \& Saavedra, 1996) and more divergent (Nemeth, 1986) than those in settings in which decision makers all agree, because the former include multiple perspectives simultaneously. Leonard-Barton (1995) suggests that clashes among different ideas spur creativity by fuelling 
continuous reexaminations of any dominant viewpoint at any particular point in time. Similarly, Amabile, Conti, Coon, Lazenby, and Herron (1996) argue that task conflict injects novelty into organizations because it seeks to change the suboptimal, current organizational situation. Therefore, task conflict should prompt employee creativity by promoting the identification of organizational problems and encouraging novel solutions to these problems.

Hypothesis 1: There is a positive relationship between task conflict and employee creativity.

Despite the creative potential of task conflict, various challenges may disrupt this connection, including employees' adherence to and comfort with their current expertise (Schneider et al., 1995) and anticipation of organizational resistance to novel ideas (Zhou \& George, 2001). In light of these challenges, we consider two contingencies that might influence this baseline relationship between task conflict and employee creativity: learning orientation and goal congruence.

\section{Moderating Role of Learning Orientation}

Employee learning orientation should enhance the positive relationship between task conflict and creativity. As mentioned previously, a learning orientation reflects employees' propensity to update and expand their current knowledge set continuously (Dweck, 1986; Porter \& Tansky, 1999). Because people with a strong learning orientation are more prone to engage in active experimentation, such that they refine their own ideas by including others' ideas (Baum, Bird, \& Singh, 2011), they should be better positioned to leverage conflicting perspectives into creative insights (Gong et al., 2009). Thus, a strong learning orientation provides a better understanding of how to expand one's own knowledge set and effectively integrate it with the differing perspectives provided by others (Dweck \& Leggett, 1988). It also enhances employees’ flexibility, in terms of which novel solutions they apply to particular organizational problems, 
even if those solutions would involve significant upheaval of the current situation (Button et al., 1996). In short, the inclination to develop new knowledge, as stimulated by a learning orientation, increases employees' versatility in leveraging conflicting viewpoints into creative outcomes (Brett \& VandeWalle, 1999).

Moreover, employees with a strong learning orientation tend to be attracted to complex, challenging work situations (Ames \& Archer, 1988) and may view the application of conflicting viewpoints to novel idea generation as a source of personal growth and fulfillment (VandeWalle et al., 1999). Thus, these employees not only have a greater ability to exploit task conflict but also may consider it desirable to apply their learning efforts to conflict situations (Maurer, Wrenn, Pierce, Tross, \& Collins, 2003). A strong learning orientation facilitates persistence (Brett \& VandeWalle, 1999) and thus may stimulate an intrinsic motivation to turn conflict situations into creative outcomes. Similarly, the notion of self-regulated learning reflects the idea that learning-oriented people are more motivated to integrate conflicting opinions into their own knowledge set to enhance their prospects for achieving a desirable situation, for themselves and their organization (Boekaerts, 1997). Thus, we expect a positive interaction effect between task conflict and learning orientation for employee creativity.

Hypothesis 2: The positive relationship between task conflict and employee creativity is moderated by learning orientation, such that the relationship is stronger at higher levels of learning orientation.

\section{Moderating Role of Goal Congruence}

The instrumentality of task conflict for employee creativity instead may be attenuated at higher levels of goal congruence. High levels of goal congruence with organizational peers imply a work context that imposes organizational goals on employees (Smith \& Tushman, 2005) and stimulates consensus in decision making (Homburg et al., 1999). Such work contexts limit the 
application of task conflict for generating creative ideas, because employees may fear that such behaviors will induce strong organizational resistance and go against the preferences of their peers (De Clercq, Menguc, \& Auh, 2009; Enz, 1988; Zhou \& George, 2001). When goal congruence is high, employees thus may experience normative pressures not to upset the status quo, which diminishes their propensity to apply the insights gained from opposing viewpoints into creative outcomes.

High levels of goal congruence also suggest that employees generally are satisfied with how the organization is functioning and where it is heading (Nahapiet \& Ghoshal, 1998). In this situation, employees likely adhere to prevailing norms and practices (Vancouver et al., 1994), informed by a common goal set, which does not encourage them to consider how conflicting viewpoints might produce creative solutions to organizational problems (Milliken et al., 2003; Richter, Hirst, van Knippenberg, \& Baer, 2012). Because goal congruence can hamper employees' openness to others' different opinions, the associated path dependencies may prevent task conflict from contributing to creative behaviors (Jackson, Joshi, \& Erhardt, 2003; Nelson \& Winter, 1982). Therefore, to the extent that employees share similar goals with their organizational peers, their propensity to leverage opposing viewpoints into creative behaviors should be thwarted.

Hypothesis 3: The positive relationship between task conflict and employee creativity is moderated by goal congruence, such that the relationship is weaker at higher levels of goal congruence.

Finally, we hypothesize that the negative moderating role of goal congruence may be attenuated for employees with a high learning orientation—or alternatively, that it is augmented for employees with a low learning orientation—which suggests a three-way interaction among task conflict, goal congruence, and learning orientation. In Hypothesis 3, we postulated that at 
higher levels of goal congruence, the potential for task conflict to increase employee creativity is lower, because employees who share common goals with organizational peers are more likely influenced by the need for consensus seeking, their fear of organizational resistance to their novel ideas, and a tendency toward complacency (Homburg et al., 1999; Milliken et al., 2003; Scheidner et al., 1995; Zhou \& George, 2001). We expect that these challenges will be subdued when employees have a stronger learning orientation. Employees with a strong learning orientation are more likely to invest significant effort in exploring novel ways to integrate and leverage conflicting viewpoints (Ames \& Archer, 1988), which makes it more likely that they can convince others of the usefulness of their novel ideas, even if these ideas are at odds with the current goal set. A strong learning orientation also enables employees to recognize how their own adherence to the common goal set may hamper their ability to generate novel ideas from their conflicting viewpoints. Thus, the consensus seeking and complacency effects associated with high goal congruence levels should be mitigated when learning orientation is high. Employees who are eager to learn new skills are more likely to find an adequate answer to organizational peers who resist the associated changes and less likely to take the organization's existing goal set for granted (Wilkins \& London, 2006), so the inhibiting role of goal congruence for the conversion of task conflict into employee creativity will be thwarted.

Conversely, the inhibiting role of goal congruence may become more salient when learning orientation is low, because employees' limited propensity to expand their current skills promotes their reliance on the existing, common goal set (Wilkins \& London, 2006). A low learning orientation makes it more likely that employees value and emphasize prevailing organizational goals (VandeWalle et al., 1999), which mitigates their ability to turn conflicting opinions into creative solutions in the presence of goal congruence. Moreover, employees who 
are less prone to update their skills are less able to convince organizational peers to leverage conflicting viewpoints into creative outcomes, to the extent that those outcomes jeopardize the current goal set. In short, when learning orientation is low, the stifling effect of goal congruence on the conversion of task conflict into employee creativity will be more pronounced.

Hypothesis 4: The negative interaction effect between task conflict and goal congruence on employee creativity is moderated by learning orientation, such that this negative interaction effect is weaker at higher levels of learning orientation.

\section{Methodology}

\section{Sample and Data Collection}

We collected data from employees working for a private, for-profit logistics organization located in Mexico. The organization, founded less than 10 years ago, distributes pharmaceutical products. It has enjoyed spectacular growth since its inception and employs more than 1,000 people. Our focus on a single organization avoids the presence of unobserved differences in the external environments of organizations; different organizations may face different external competitive pressures that affect the urgency of creative behaviors (Dayan \& Di Benedetto, 2011). The data collection relied on a survey instrument, which was distributed in two rounds. First, we asked 1,100 employees to assess the extent to which they experience task conflict in their interactions with colleagues, are eager to learn new skills, and share common goals with organizational peers. We received 746 responses, for a response rate of $68 \%$, likely due to the strong support for this study expressed by the organization's top management. Second, one month later, the immediate supervisors of the first-round respondents assessed their employees' creativity. We received completed responses from 84 supervisors who assessed 707 employees in total. The average employee was 34 years of age and had worked for the organization for 3.5 years; $78 \%$ were men. 
The surveys were originally prepared in English and then translated into Spanish. To avoid cultural bias and ensure validity, the Spanish versions were back-translated into English (Brislin, Lonner, \& Thorndike, 1973). In addition, we pretested a preliminary version of the two surveys with two different sets of employees who did not participate in the actual data collection. By incorporating the feedback from these employees into a revised version of the surveys, we increased the readability of the questions and the data quality. For both survey rounds, we guaranteed the participants complete confidentiality, repeatedly assured them that there were no right or wrong answers, and asked them to answer the questions as honestly as possible, to minimize the possibility that their responses would be subject to social desirability or acquiescence biases (Spector, 2006).

\section{Measures}

The survey items for the four focal constructs used seven-point Likert scales, ranging from 1 ("strongly disagree”) to 7 (“strongly agree”). To avoid common source bias, which can arise if the same respondents assessed both their creative behaviors and the factors that influence these behaviors, we asked different respondents to rate the dependent variable versus the other variables. Specifically, employees assessed the level of task conflict in their interactions with colleagues, their learning orientation, and their goal congruence with colleagues, but their immediate supervisors assessed employee creativity.

Employee creativity. To measure supervisors' assessments of employee creativity, we used three items drawn from previous research (Janssen, 2001; Scott \& Bruce, 1994), namely, “This employee often creates new ideas for improvement," "This employee often searches out 
new working methods, techniques, or instruments," and "This employee often generates original solutions to problems" (alpha $=.940){ }^{4}$

Task conflict. We measured task conflict with a four-item scale based on prior literature on intra-firm conflict (De Clercq, Thongpapanl, \& Dimov, 2009; Jehn \& Mannix, 2001). The items included "My colleagues and I often have conflicting opinions about projects," "My colleagues and I often have conflicting ideas," “The tasks pursued by my colleagues and myself are often incompatible with each other," and "My colleagues and I often have disagreements about task-related issues" (alpha $=.844)$.

Learning orientation. We measured employees' learning orientation with four representative items drawn from VandeWalle (1997). The respondents assessed whether "I often read materials (books, articles, Internet, etc.) to improve my abilities," "I like to take on a challenging task that I can learn a lot from," "I often look for opportunities to develop new skills and knowledge," and "I enjoy challenging and difficult tasks where I can earn new skills" (alpha $=.781)$.

Goal congruence. Goal congruence was measured with four items adopted from previous studies (De Clercq, Thongpapanl, \& Dimov, 2011; Tsai \& Ghoshal, 1998). Respondents assessed whether "my colleagues and themselves share a similar vision regarding the company's future," "my colleagues and themselves think alike on most issues with respect to the company," "most of my objectives are fully aligned with those of my colleagues," and "my colleagues and myself perceive work-related problems as mutual problems" (alpha $=.783)$.

Control variables. To account for alternative explanations of employee creativity, we controlled for three demographic characteristics: age, gender, and organizational tenure,

\footnotetext{
${ }^{4}$ Employee creativity captures the generation of novel and useful ideas, which represents the initial step in innovative behavior, a comprehensive process that also includes idea promotion and implementation (used in De Clercq, Dimov, \& Belausteguigoitia, 2014).
} 
consistent with previous research (Gong et al., 2009). We also controlled for whether the organizational climate was supportive of creative behaviors, measured with an item adapted from Scott and Bruce (1994): "My company is open to having its people solve problems in creative ways."

Following Anderson and Gerbing (1988), we estimated a four-factor measurement model using AMOS 22.0. The confirmatory factor analysis showed significant factor loadings, normalized residuals less than 2.58, and modification indices less than 3.84 for all scale items (Anderson \& Gerbing, 1988). The fit of the measurement model was excellent: $\chi_{(43)}^{2}=163.09$, normed fit index $=.97$, confirmatory fit index $=.98$, and root mean squared error of approximation $=.04$. We found evidence of the convergent validity of the four focal constructs in the significant loadings of their respective items in the measurement model $(\mathrm{t}>2.0$; Gerbing \& Anderson, 1988) and the magnitude of their average variance extracted (AVE) values, which exceeded the .50 threshold (Bagozzi \& Yi, 1988). In support of the discriminant validity of the four constructs, their AVE values were greater than the squared correlations between the corresponding pairs of constructs (Fornell \& Larcker, 1981), and for all six pairs of constructs, we found significant differences $\left(\Delta \chi_{(1)}^{2}<.3 .84\right)$ between the unconstrained and constrained models (Anderson \& Gerbing, 1988).

\section{Results}

Table 1 shows the zero-order correlations and descriptive statistics, and Table 2 shows the regression results. Model 1 includes the control variables, Model 2 adds task conflict, and Model 3 adds the two moderators, learning orientation and goal congruence. Models 4 adds the task conflict $\times$ learning orientation and task conflict $\times$ goal congruence interaction terms; Model 
5 adds the three-way interaction (task conflict $\times$ goal congruence $\times$ learning orientation) together with its three underlying two-way interactions, as recommended by Aiken and West (1991). ${ }^{5}$

[Insert Tables 1 and 2 about here]

The results of the control model (Model 1) indicate that creativity is higher among employees who are younger $(\beta=-.014, p<.05)$, have worked in the organization for a longer period of time ( $\beta=.082, p<.01)$, and perceive that their organization supports creative behaviors $(\beta=.054, p<.10)$. In support of our prediction in Hypothesis 1 that conflicting options fuel creative behavior, Model 2 reveals that task conflict relates positively to employee creativity $(\beta=.107, p<.05)$. Although they fall outside the theoretical focus of this study, the results in Model 3 indicate no direct effects of learning orientation and goal congruence on employee creativity, consistent with the previous mixed findings about the direct effect of a learning orientation on creativity (Hirst et al., 2009) and the trade-off between the comfort and complacency that come with common goals (Milliken et al., 2003; Nahapiet \& Ghoshal, 1998).

Model 4 supports the hypothesized invigorating effect of learning orientation $(\beta=.172, p$ $<.01)$ and the attenuating effect of goal congruence $(\beta=-.093, p<.01)$ on the task conflictemployee creativity relationship. Thus, the effectiveness of task conflict as a means of enhancing employee creativity is greater when employees exhibit a higher learning orientation (Hypothesis 2) and experience lower goal congruence with their peers (Hypothesis 3). To clarify the nature of these interactions, we plotted the effects of task conflict on employee creativity for high and low levels of learning orientation and goal congruence in Figures 2 and 3, respectively, combined

\footnotetext{
${ }^{5}$ Considering the nested nature of our data set, we assessed whether it was appropriate to apply hierarchical linear modeling to test our hypotheses. However, the low interclass correlation coefficients for task conflict (ICC[1] = .03 and ICC $[2]=.23$ ) and goal congruence $(\mathrm{ICC}[1]=.04$ and ICC $[2]=.28)$, which arguably are constructs that capture group-level phenomena, indicated that multilevel analysis was not appropriate for this study, possibly because the survey questions asked employees to assess their colleagues in general, not colleagues who work in the same department. To test the robustness of the results, we also controlled for supervisor fixed effects in a post hoc analysis; the findings remained consistent with those in Table 2.
} 
with a simple slope analysis for each (Aiken \& West, 1991). The results in Figure 2 indicate that the relationship between task conflict and employee creativity is positive at high learning orientation levels $(\mathrm{t}=2.766, p<.01)$, but it becomes insignificant at low learning orientation levels $(\mathrm{t}=-1.463, n s)$. Similarly, Figure 3 shows that the relationship between task conflict and employee creativity is positive with low goal congruence $(\mathrm{t}=2.264, p<.05)$ but becomes insignificant with high goal congruence $(\mathrm{t}=-.620, n s)$.

[Insert Figures 2 and 3 about here]

We also found support for Hypothesis 4 in the positive three-way interaction among task conflict, goal congruence, and learning orientation in Model $4(\beta=.119, p<.05)$. Thus, the negative moderating effect of goal congruence on the task conflict-employee creativity relationship is weaker at higher levels of learning orientation. To clarify this interaction, we plot the moderating effect of goal congruence on the task conflict-employee creativity relationship at high versus low levels of learning orientation in Figure 4, Panels A and B, respectively. At low levels of learning orientation (Figure 4B), the pattern of the interaction plot is similar to that in Figure 3: Task conflict diminishes employee creativity at high levels of goal congruence and enhances employee creativity at low levels. However, at high levels of learning orientation (Figure 4A), the two lines are almost parallel, indicating the lack of an interaction effect between task conflict and goal congruence. We also followed Dawson and Richter (2006) and assessed whether the slope differences in Figure 4, Panels A and B, were significant. Although the slope difference in Figure 4A is not significant $(\mathrm{t}=.065, n s)$, the difference is significant in Figure 4B $(\mathrm{t}=-3.521, p<.001)$, in further support of Hypothesis 4.

[Insert Figures 4A and 4B about here]

\section{Discussion}


From a theoretical perspective, this study contributes to research on employee creativity by elaborating on how two critical personal and contextual factors (learning orientation and goal congruence) affect the instrumentality of task conflict for enhanced creativity. The lack of previous attention to this issue is somewhat surprising, in light of the widespread recognition that novel, useful ideas stem from employees' ability to continuously update and refine their current knowledge base (Gong et al., 2009), as well as their perceptions that these ideas may be acceptable to organizational peers (LePine \& Van Dyne, 1998). A learning orientation is a personal characteristic that speaks to a person's ability to refine his or her knowledge set continuously (Brett \& VandeWalle, 1999), whereas goal congruence is a contextual characteristic that reflects how organizational members adhere to a common goal set (Vancouver \& Schmitt, 1991). We posited that a learning orientation helps employees leverage task conflict into enhanced creativity and that goal congruence challenges this process. We also argued that the tendency for consensus seeking that comes with goal congruence is particularly salient among employees with a low learning orientation. Our research largely supports these theoretical arguments.

The direct positive effect of task conflict is in line with previous research on the beneficial role of content-related disagreements in creative settings (Amason, 1996; Jehn \& Mannix, 2001). Employees' ability to generate novel ideas depends on the confrontation of their own knowledge set with opposing viewpoints held by organizational peers (Hoever et al., 2012). Task conflict triggers employees to scrutinize organizational problems in greater detail and increases the range of possible solutions to problems (Carnevale \& Probst, 1998). It also boosts employees' motivation to collaborate with one another to find new ideas and insights that solve their mutual problems (De Dreu \& West, 2001; Nemeth \& Staw, 1989). Notably, some research 
has suggested that excessive task conflict may reduce employee creativity, because the associated negative stress and interpersonal tension prevent employees from focusing on the problem at hand and thus steers them away from generating novel ideas (Shalley, Zhou, \& Oldham, 2004; Wall \& Callister, 1995). For example, De Dreu (2006) finds a curvilinear relationship between task conflict and team innovation. A post hoc analysis did not indicate the presence of such a curvilinear relationship between task conflict and employee creativity in our sample though, possibly because the level of task conflict in the organization we studied was relatively low (i.e., mean $=2.88$ on a seven-point scale).

Furthermore, our findings reveal that the potency with which task conflict can enhance employee creativity increases at higher levels of learning orientation. Employees who continuously look for new knowledge can better gain novel insights from the confrontation of different viewpoints and thus can leverage content-related disagreements into creative outcomes. Moreover, learning-oriented employees are more likely to transform conflict situations into creative outcomes, because of the personal satisfaction they experience when applying their learning efforts to conflict situations (Maurer et al., 2003). Thus, a strong learning orientation facilitates the creative exploitation of task conflict, because it increases the person's ability to integrate contrasting opinions effectively and her or his motivation to find creative solutions to organizational problems. Conversely, task conflict does not make a significant contribution to creativity when employees' learning orientation is low (Figure 2).

Our results also support a significant negative interaction effect between task conflict and goal congruence. In particular, we find a positive relationship between task conflict and employee creativity when goal congruence is low, but the relationship is insignificant at high levels of goal congruence (Figure 3). Although goal congruence may fuel positive work 
outcomes, such as organizational commitment and job satisfaction (Vancouver et al., 1994), its combined effect with task conflict on employee creativity is more complex. Employees whose personal goals are subordinated to a goal set that they hold in common with their organizational peers are subject to an implicit control system (Enz, 1988; Nahapiet \& Ghoshal, 1998), such that they fear that their novel ideas, which are likely to undermine the common goal set, will prompt organizational resistance. This consensus-seeking mechanism decreases employees' propensity to evaluate opposing opinions critically, even if these opinions would be useful for creating novel ideas (Homburg et al., 1999; Richter et al., 2012). High levels of goal congruence also may ossify employees' assumptions about current organizational practices (Jackson et al., 2003; Milliken et al., 2003), which fuels a tendency toward complacency and makes it more challenging to translate opposing viewpoints into creative solutions. Overall, our study shows that research focusing on the positive consequences of goal congruence may have overlooked its "costs" in creative settings and underestimated the possibility that these costs outweigh the benefits, because of the desire for consensus seeking that goal congruence generates (Gedajlovic, Honig, Moore, Payne, \& Wright, 2013; Homburg et al., 1999). Our results address this oversight by citing the role of goal congruence in mitigating the ability to transform opposing viewpoints into creative outcomes.

Finally, this study reveals that the pressure for consensus seeking that comes with goal congruence is particularly salient among employees with a low learning orientation (Figure 4B), but goal congruence does not have an impact on the usefulness of task conflict when learning orientation is high (Figure 4A). On the one hand, low levels of learning orientation exacerbate the challenge that goal sharing poses to the effective translation of task conflict into employee creativity. When employees are rather passive in their search for new knowledge, they are less 
able to counter anticipated resistance to their novel ideas, so the likelihood that goal congruence stifles the conversion of opposing viewpoints into creative outcomes increases (Milliken et al., 2003). On the other hand, the propensity to learn continuously balances out the consensusseeking tendency that comes with a common goal set, such that employees can turn differing viewpoints into creative behaviors, despite the presence of high goal congruence. In this case, it is also less likely that employees feel intimidated by the organization's current goal set (Enz, 1988), so their desire to be perceived as a loyal colleague who does not upset the status quo becomes less relevant.

\section{Managerial Implications}

From a practical perspective, this study suggests that to stimulate creativity among employees, HR managers should encourage discussions of opposing viewpoints, as well as attend to ways to exploit such discussions to ensure that employees realize their creative potential. In their efforts to enhance employees' creative behavior, HR managers should combine task conflict with appropriate individual employee characteristics (learning orientation) and work contexts (goal adjustment). The effective translation of task conflict into employee creativity, even when conflict provides a useful platform for novel idea generation, may encounter various challenges before it bears fruitful results, including employees' strong adherence to their current skill set and expertise or anticipation of significant organizational resistance to their novel ideas (Sutton \& Hargadon, 1996).

To enhance employee creativity, HR managers should explicitly acknowledge that task conflicts are most effective at generating creative outcomes when employees exhibit a strong learning orientation and are willing to update their knowledge base. Thus, organizations with strong creative aspirations that seek to maximize the benefits of conflict-laden discussions should 
proactively recruit employees who have a natural disposition toward learning. However, people's learning orientation is not set in stone and can fluctuate across situational conditions (Button et al., 1996; Dragoni, Tesluk, Russell, \& Oh, 2009). Because employees' learning orientation is malleable (Van Hooft \& Noordzij, 2009), it offers an excellent opportunity for managerial intervention. Employees may become more learning oriented to the extent that they are required to undertake challenging tasks or are stimulated by their supervisors to question their current knowledge set (Dragoni, 2005)

To boost the influence of a learning orientation on the effective exploitation of task conflict, HR managers also could offer various training opportunities to employees, such as dedicated training programs outside the workplace, structured on-the-job training (Jacobs, 2003), and informal learning, all of which are significant sources of employee development (Enos, Kehrhahn, \& Bell, 2003). Such a broad range of training options can not only create an organizational culture that stimulates learning but also reinforce the capability of learningoriented employees to integrate their own knowledge base with those of their organizational peers, with the ultimate goal of generating novel, useful ideas (Choi \& Jacobs, 2011). Therefore, organizational policies should be formulated to empower HR managers to flexibly plan, implement, and evaluate employee learning. Excessively strict policies that focus only on formal learning programs instead may limit the possibilities for effectively matching continuous knowledge renewal among employees with the exploitation of task conflict.

Further, HR managers should be aware that high levels of goal congruence can threaten the potential for task conflict to spur creativity. Although there are some benefits of avoiding excessive differences among employees, HR managers might encourage brainstorming and goal review sessions, to ensure that employees' tendency to stick to the common goal set does not 
constrain useful task conflicts from promoting creative behaviors. Overall, HR managers who seek to stimulate the creative potential inherent to task conflict should take a proactive approach and stimulate flexibility in organizational goal setting (Ketokivi \& Castañer, 2004). They could provide specific feedback when employees take initiatives to adapt the current goal set and even reward such initiatives if they contribute to the creation of novel ideas that benefit the organization (De Clercq, Castañer, \& Belausteguigoitia, 2011; London \& Sessa, 2006). Feedback about such goal adjustments also should be accompanied by appropriate resources and coaching, so individual employees gain a better understanding of how goal adjustments can increase the effectiveness of their task conflict. Our findings with respect to the three-way interaction of task conflict, learning orientation, and goal congruence also indicate that strategies to avoid excessive adherence to a common goal set should be targeted particularly at employees with a low learning orientation.

Finally, this study has implications for the recruitment and training of appropriate organizational leaders, who need to increase the instrumentality of conflicting viewpoints for creative outcomes. The benefits of task conflict for spurring employee creativity can be enhanced to the extent that organizational leaders focus on employees' personal growth and development and are flexible in their evaluations of employee performance in relation to a current organizational goal set. This issue might be particularly important for employees who have recently joined the organization (Harris, Li, Boswell, Zhang, \& Xie, 2014). A leader who is focused strictly on preset performance standards and goals may prevent new employees from applying their different knowledge bases to the creation of novel ideas. Therefore, the training and evaluation of organizational leaders should be based, at least in part, on how employees rate their leaders in terms of available learning opportunities and openness to reconsidering well- 
established performance goals. Organizations with strong creative aspirations also can benefit from exposing employees to inspiring leader role models (Brown \& Trevino, 2014), who communicate the joy that they derive from their personal, continuous learning efforts and their contributions to adjusting organizational goals.

\section{Limitations and Future Research}

This study has some limitations that offer avenues for further research. First, some caution is needed before we draw causal inferences, in that the focal task conflict-employee creativity relationship could be susceptible to reverse causality. Employees who engage in creative behaviors may undermine the privileges of organizational peers, which could spur task conflict (Amason, 1996; Sutton \& Hargadon, 1996). Although our theorizing was grounded in extant theory and we imposed a one-month time gap between our assessment of task conflict and employee creativity, further research could use longitudinal designs that span longer periods to investigate the causal processes that link task conflict and employee creativity, as well as the boundary conditions that might influence the process. Second, this study focused on explaining employee creativity, rather than the performance outcomes of creative behaviors. To extend this conceptual framework, further research might investigate whether and how employees' creation of novel and useful ideas, as a response to task conflict, influences their job performance, as well as how their learning orientation and goal congruence inform this causal process. Third, an empirical limitation of this study is that we relied on employees' assessments of task conflict and goal congruence in relation to their colleagues in general, rather than immediate colleagues who report to the same supervisor. More refined measures could support the application of multilevel techniques that investigate the combined impacts of individual- and group-level factors on employee creativity. 
Fourth, by focusing on two specific contingency factors, we ignored alternative factors that may be relevant for the successful conversion of task conflict into employee creativity. For example, it would be interesting to examine the moderating roles of employees' performance orientation in the application of task conflict to creativity. In contrast to a learning orientation, a performance orientation is externally focused and emphasizes the demonstration of competences to others instead of personal development (VandeWalle, 1997). Such an external focus might turn employees away from leveraging conflicting viewpoints into creative output. In terms of goal congruence, we did not explicate the nature of the common goal set. Instead, we assumed that employees' perceptions of goal congruence diminish their motivation to apply their conflicting knowledge bases to the generation of creative ideas, because these ideas may upset the current goal set. This pattern is consistent with our empirical findings. However, additional research could assess the extent to which the current goal set includes elements of innovation (Choi, 2004) and thereby consider whether the mitigating effect of goal congruence on the task conflict-employee creativity relationship changes in strength, or even direction, with the varying content of an organization's goals. Such studies also could investigate how organizations balance their creative aspirations with the development of harmonious, congruent relationships among organizational members and the role that empowered new organizational members might play in this process (Harris et al., 2014). Research also could explicitly account for the extent to which creativity is required in employees' job descriptions and use more refined measures of their perceptions of organizational support for creativity.

Fifth, our results are based on an organization in Mexico. Although our theoretical arguments were general and not country-specific, cultural factors could interfere with our conceptual framework. For example, in an uncertainty avoidant country such as Mexico, 
employees may be highly sensitive to the stress that ensues from task conflict (Hofstede, 2001), so the potency with which higher learning orientation and lower goal congruence fuel the exploitation of such conflict may be stronger than it would be in more risk-prone countries. Cross-country studies could provide insights into the relative importance of employees' personal and contextual resources for translating task conflict into higher creativity across different cultural contexts.

\section{Conclusion}

This study directs greater attention to the question of when task conflict is most useful for enhancing employee creativity. The potential for opposing viewpoints to spur creativity gets enhanced to the extent that employees are more eager to refine their knowledge base continuously and do not feel constrained by the presence of a common goal set. We hope that this work can function as a platform for further investigations of strategies that HR managers can use to stimulate the translation of conflict situations into greater creativity among their employees, through appropriate matches between the situations and specific personal and contextual characteristics. 


\section{References}

Aiken, L. S., \& West, S. G. (1991). Multiple regression: Testing and interpreting interactions. Newbury Park, CA: Sage.

Amabile, T. M., Conti, R., Coon, H., Lazenby, J., \& Herron, M. (1996). Assessing the work environment for creativity. Academy of Management Journal, 39, 1154-1184.

Amason, A. C. (1996). Distinguishing the effect of functional and dysfunctional conflict on strategic decision making: Resolving a paradox for top management teams. Academy of Management Journal, 39, 123-148.

Amason A. C., \& Schweiger D. M. (1994). Resolving the paradox of conflict, strategic decision making, and organizational performance. International Journal of Conflict Management, 5(3), 239-253.

Ames, C., \& Archer, J. (1988). Achievement goals in the classroom: Students' learning strategies and motivation processes. Journal of Educational Psychology, 80(3), 260-267.

Anderson, J. C., \& Gerbing, D. W. (1988). Structural equation modeling in practice: A review and recommended two step approach. Psychology Bulletin, 1033, 411-423.

Bagozzi, R. P. \& Yi, Y. (1988). On the evaluation of structural equation models. Journal of the Academy of Marketing Science, 16, 74-94.

Baum, J., Bird, B., \& Singh, S. (2011). Practical intelligence of entrepreneurs: Antecedents and a link with new venture growth. Personnel Psychology, 64(2), 397-425.

Binyamin, G., \& Carmeli, A. (2010). Does structuring of human resource management processes enhance employee creativity? The mediating role of psychological availability. Human Resource Management, 49(6), 999-1024.

Boekaerts, M. (1997). Self regulated learning: A new concept embraced by researchers, policy makers, educators, teachers, and students. Learning and Instruction, 7(2), 161-186.

Brett, J. F., \& VandeWalle, D. (1999). Goal orientation and goal content as predictors of performance in a training program. Journal of Applied Psychology, 84(6), 863-873.

Brislin, R. W., Lonner, W., \& Thorndike, R. M. (1973). Cross-cultural research methods. New York: John Wiley \& Sons.

Brown, M., \& Treviño, L. (2014). Do role models matter? An investigation of role modeling as an antecedent of perceived ethical leadership. Journal of Business Ethics, 122(4), 587-598.

Button, S., Mathieu, J., \& Zajac, D. (1996). Goal orientation in organizational behaviour research: A conceptual and empirical foundation. Organizational Behaviour and Human Decision Processes, 67, 26-48.

Carnevale, P.J., \& Probst, T.M. (1998). Social values and social conflict in creative problem solving and categorization. Journal of Personality and Social Psychology, 74, 1300-1309.

Chen, M.-H., \& Chang, Y.-C. (2005). The dynamics of conflict and creativity during a project's life cycle: A comparative study between service-driven and technology-driven teams in Taiwan. International Journal of Organizational Analysis, 13(2), 127-150.

Choi, J. N. (2004). Person-environment fit and creative behavior: Differential impacts of supplies-values and demands-abilities versions of fit. Human Relations, 57, 531-552.

Choi, W., \& Jacobs, R.L. (2011). Influences of formal learning, personal learning orientation, and supportive learning environment on informal leaning. Human Resource Development Quarterly, 22(3), 239-257.

Christensen, C., \& Bower, J. L. (1996). Customer power, strategic investment, and the failure of leading firms. Strategic Management Journal, 17(3), 197-218. 
Dawson J,F., \& Richter, A.W. (2006). Probing three-way interactions in moderated multiple regression: Development and application of a slope difference test. Journal of Applied Psychology, 91, 917-926.

Dayan, M., \& Di Benedetto, C. (2011). Team intuition as a continuum construct and new product creativity: The role of environmental turbulence, team experience, and stress. Research Policy, 40(2), 276-286.

De Church, L.A., \& Marks, M.A. (2001). Maximizing the benefit of task conflict: The role of conflict management. International Journal of Conflict Management, 12, 4-22.

De Clercq, D., Castañer, X., \& Belausteguigoitia, I. (2011). Entrepreneurial initiative selling within organizations: Toward a more comprehensive motivational framework. Journal of Management Studies, 48(6), 1269-1290.

De Clercq, D., Dimov, D., \& Belausteguigoitia, I. (2014). Perceptions of adverse work conditions and innovative behavior: The buffering roles of relational resources. Entrepreneurship Theory and Practice, forthcoming.

De Clercq, D., Menguc, B., \& Auh, S. (2009). Unpacking the relationship between innovation strategy and firm performance: The role of task conflict and political activity. Journal of Business Research, 62(11), 1046-1053.

De Clercq, D., Thongpapanl, N., \& Dimov, D. (2009). When good conflict gets better and bad conflict becomes worse: The role of social capital in the conflict-innovation relationship. Journal of the Academy of Marketing Science, 37(3), 283-297.

De Clercq, D., Thongpapanl, N., \& Dimov, D. (2011). A closer look at cross-functional collaboration and product innovativeness: Contingency effects of structural and relational Context. Journal of Product Innovation Management, 28(5), 680-699.

De Dreu, C.K. (2006). When too little or too much hurts: Evidence for a curvilinear relationship between task conflict and innovation in teams. Journal of Management, 32(1), 83-107.

De Dreu, C.K., \& Weingart, L. R. (2003). Task versus relationship conflict, team performance, and team member satisfaction: A meta-analysis. Journal of Applied Psychology, 88(4), 741.

De Dreu, C.K., \& West, M.A. (2001). Minority dissent and team innovation: The importance of participation in decision making. Journal of Applied Psychology, 86, 1191-1201.

Dragoni, L. (2005). Understanding the emergence of state goal orientation in organizational work groups: The role of leadership and multilevel climate perceptions. Journal of Applied Psychology, 90, 1084-1095.

Dragoni, L., Tesluk, P. E., Russell, J. E. A., \& Oh, I.-S. (2009). Understanding managerial development: Integrating developmental assignments, learning orientation, and access to developmental opportunities in predicting managerial competencies. Academy of Management Journal, 52, 731-743.

Dweck, C.S. (1986). Motivational processes affecting learning. American Psychologist, 41, 1040-1048.

Dweck, C. S., \& Leggett, E. L. (1988). A social-cognitive approach to motivation and personality. Psychological Review, 95, 256-273.

Eisenhardt, K. M., \& Schoonhoven, C. B. (1990). Organizational growth: Linking founding team, strategy, environment, and growth among US semiconductor ventures, 1978-1988. Administrative Science Quarterly, 35(3), 504-529.

Enos, M.D., Kehrhahn, M.T., \& Bell, A. (2003). Informal learning and the transfer of learning: How managers develop proficiency. Human Resource Development Quarterly, 14(4), 368387. 
Enz, C. A. (1988). The role of value congruity in intraorganizational power. Administrative Science Quarterly, 33, 284-304.

Farh, J. L., Lee, C. \& Farh, C. I. C. (2010). Task conflict and team creativity: A question of how much and when. Journal of Applied Psychology, 95, 1173-1180.

Fornell, C., \& Larcker, D. F. (1981). Evaluating structural equation models with unobservable variables and measurement error. Journal of Marketing Research, 18, 39-50.

Gedajlovic, E., Honig, B., Moore, C. B., Payne, G. T., \& Wright, M. (2013). Social capital and entrepreneurship: A schema and research agenda. Entrepreneurship Theory and Practice, 37(3), 455-478.

Gerbing D. W., \& Anderson, J. C. (1988). An updated paradigm for scale development incorporating unidimensionality and its assessment. Journal of Marketing Research, 25(2), 186-192.

Gilbert, C. (2005). Unbundling the structure of inertia: Resource versus routine rigidity. Academy of Management Journal, 48(5), 741-763.

Gilson, L. L., Mathieu, J. E., Shalley, C. E., \& Ruddy, T. M. (2005). Creativity and standardization: Complementary or conflicting drivers of team effectiveness? Academy of Management Journal, 48, 521-531.

Gong, Y., Huang, J. C., \& Farh, J. L. (2009). Employee learning orientation, transformational leadership, and employee creativity: The mediating role of employee creative self efficacy. Academy of Management Journal, 52(4), 765-778.

Harris, T. B., Li, N., Boswell, W. R., Zhang, X. A., \& Xie, Z. (2014). Getting what's new from newcomers: Empowering leadership, creativity, and adjustment in the socialization context. Personnel Psychology, 67, 567-604.

Hirschman, A. (1970). Exit, voice, and loyalty. Responses to decline in firms, organizations, and states. Cambridge, MA: Harvard University Press.

Hirst, G., van Knippenberg, D., \& Zhou, J. (2009). A cross-level perspective on employee creativity: Goal orientation, team learning behavior, and individual creativity. Academy of Management Journal, 52(2), 280-293.

Hoever, I. J., van Knippenberg, D., van Ginkel, W. P., \& Barkema, H. G. (2012). Fostering team creativity: Perspective taking as key to unlocking diversity's potential. Journal of Applied Psychology, 97(5), 982-996.

Hofstede, G. (2001). Culture's consequences: Comparing values, behaviors, institutions and organizations across nations ( $2^{\text {nd }}$ ed.). Thousand Oaks, CA: Sage.

Hollenbeck, J.R., Colquitt, J.A., Ilgen, D.R., LePine, J.A., \& Hedlund, J. (1998). Accuracy decomposition and team decision making: Testing theoretical boundary conditions. Journal of Applied Psychology, 83, 494-500.

Homburg, C., Krohmer, H., \& Workman, J. P. Jr. (1999). Strategic consensus and performance: The role of strategy type and market-related dynamism. Strategic Management Journal, 20, 339-397.

Huang, J.-C. (2012). The relationship between conflict and team performance in Taiwan: The moderating effect of goal orientation. International Journal of Human Resource Management, 23(10), 2126-2143.

Jackson, S. E., Joshi, A., \& Erhardt, N. L. (2003). Recent research on team and organizational diversity: SWOT analysis and implications. Journal of Management, 29, 801-830.

Jacobs, R.L. (2003). Structured on-the-job training: Unleashing employee expertise in the workplace. San Francisco, CA: Berrett-Koehler. 
Janssen, O. (2001). Fairness perceptions as a moderator in the curvilinear relationships between job demands, and job performance and job satisfaction. Academy of Management Journal, 44, 1039-1050.

Janssen, O. \& Giebels, E. (2013). When and why creativity-related conflict with coworkers can hamper creative employees' individual job performance. European Journal of Work and Organizational Psychology, 22(5), 574-587.

Jehn, K. A. (1995). A multimethod examination of the benefits and detriments of intragroup conflict. Administrative Science Quarterly, 40, 256-282.

Jehn, K. A., \& Bendersky, C. (2003). Intragroup conflict in organizations: A contingency perspective on the conflict-outcome relationship. In R. M. Kramer \& B. M. Staw (Eds.), Research in organizational behavior, vol. 25: 187-242. New York: Elsevier.

Jehn, K. A., \& Mannix, E. A. (2001). The dynamic nature of conflict: A longitudinal study of intragroup conflict and group performance. Academy of Management Journal, 44, 238-251.

Jehn, K. A., Northcraft, G. B., \& Neale, M. A. (1999). Why differences make a difference: A field study of diversity, conflict, and performance in workgroups. Administrative Science Quarterly, 44(4), 741-763.

Kabanoff, B. (1991). Equity, equality, power and conflict. Academy of Management Review, 16, 416-441

Kellermanns, F.W., Walter, J., Lechner, C., \& Floyd, S.W. (2012). The lack of consensus about strategic consensus: Advancing theory and research. Journal of Management, 31, 719-737.

Ketokivi, M., \& Castañer, X. (2004). Strategic planning as an integrative device. Administrative Science Quarterly, 49, 337-365.

Kim, T. Y., Hon, A. H. Y., \& Crant, J. M. (2009). Proactive personality, employee creativity, and newcomer outcomes: A longitudinal study. Journal of Business Psychology, 24, 93-103.

Leonard-Barton, D. (1992). Core capabilities and core rigidities: A paradox in managing new product development. Strategic Management Journal, 13, 111-125.

Leonard-Barton, D. (1995). Wellsprings of knowledge: Building and sustaining the sources of innovation. Boston: Harvard Business School Press.

LePine, J. A., \& Van Dyne, L. (1998). Predicting voice behaviors in work groups. Journal of Applied Psychology, 83, 853-868.

Livingstone, L. P., Nelson, D. L., \& Barr, S. H. (1997). Person-environment fit and creativity: An examination of supply-value and demand-ability versions of fit. Journal of Management, 23, 119-146.

London, M., \& Sessa, V. (2006). Group feedback for continuous learning. Human Resource Development Review, 5(3), 303-329.

Luo, X., Slotegraaf, R. J., \& Pan, X. (2006). Cross-functional "coopetition": The simultaneous role of cooperation and competition within firms. Journal of Marketing, 70, 67-80.

Maurer, T., Wrenn, K., Pierce, R., Tross, S., \& Collins, W. (2003). Beliefs about 'improvability' of career-relevant skills: Relevance to job/task analysis, competency modeling, and learning orientation. Journal of Organizational Behaviour, 24, 107-131.

McDonough, E. F., III. (2000). Investigation of factors contributing to the success of crossfunctional teams. Journal of Product Innovation Management, 17(3), 221-235.

Milliken, F. J., Bartel, C. A., \& Kurtzberg, T. (2003). Diversity and creativity in work groups: A dynamic perspective on the affective and cognitive processes that link diversity and performance. In P. Paulus \& B. Nijstad (Eds.), Group creativity: 32- 62. New York: Oxford University Press. 
Nahapiet, J., \& Ghoshal, S. (1998). Social capital, intellectual capital, and the organizational advantage. Academy of Management Review, 23, 242-268.

Nelson, R. \& Winter, S. (1982). An evolutionary theory of economic change. Boston: Harvard University Press.

Nemeth, C. J. (1986). Differential contributions of majority and minority influence. Psychological Review, 93(1), 23-32.

Nemeth, C.J., \& Staw, B.M. (1989). The tradeoffs of social control and innovation in groups and organizations. In L. Berkowitz (Ed.), Advances in experimental social psychology, Vol. 22: 175-210. New York: Academic Press.

Ocasio, W. (1997). Towards an attention-based view of the firm. Strategic Management Journal, $18,187-206$.

Oreg, S. (2003). Resistance to change: Developing an individual differences measure. Journal of Applied Psychology, 88(4), 680-693.

Pelled, L. H., Eisenhardt, K. M., \& Xin, K. R. (1999). Exploring the black box: An analysis of work group diversity, conflict, and performance. Administrative Science Quarterly, 44, 1-28.

Porter, G., \& Tansky, J. (1999). Expatriate success may depend on a "learning orientation": Considerations for selection and training. Human Resource Management, 38, 47-60.

Richter, A. W., Hirst, G., van Knippenberg, D., \& Baer, M. (2012). Creative self-efficacy and individual creativity in team contexts: Cross-level interactions with team informational resource. Journal of Applied Psychology, 97(6), 1282-1290.

Schneider, B., Goldstein, H. W., \& Smith, D. B. (1995). The ASA framework: An update. Personnel Psychology, 48, 747-771.

Scott, S. G., \& Bruce, R. A. (1994). Determinants of innovative behavior: A path model of individual innovation in the workplace. Academy of Management Journal, 37, 580-607.

Shalley, C.E., Zhou, J., \& Oldham, G.R. (2004). The effects of personal and contextual characteristics on creativity: Where should we go from here? Journal of Management, 30, 933-958.

Simons, T., \& Peterson, R. (2000). Task conflict and relationship conflict in top management teams: The pivotal role of intragroup trust. Journal of Applied Psychology, 85, 102-111.

Smith, W. K., \& Tushman, M. L. (2005). Managing strategic contradictions: A top management model for managing innovation streams. Organization Science, 16, 522-536.

Spector, P.E. (2006). Method variance in organizational research: Truth or urban legend? Organizational Research Methods, 9, 221-232.

Staw, B.M. (1984). Organizational behavior: A review and reformulation of the field's outcome variables. In M. R. Rosenzweig \& L. W. Porter (Eds.), Annual review of psychology, Vol. 35: 627-666. Palo Alto, CA: Annual Reviews.

Sutton, R. I., \& Hargadon, A. (1996). Brainstorming groups in context: Effectiveness in a product design firm. Administrative Science Quarterly, 41, 685-718.

Tsai, W., \& Ghoshal, S. (1998). Social capital and value creation: The role of intrafirm networks. Academy of Management Journal, 41, 464-476.

Vancouver, J. B., Millsap, R. E., \& Peters, P. A. (1994). Multilevel analysis of organizational goal congruence. Journal of Applied Psychology, 79, 666-679.

Vancouver, J. B., \& Schmitt, N. W. (1991). An exploratory examination of person organization fit: Organizational goal congruence. Personnel Psychology, 44, 333-352.

Van der Vegt, G.S., Emans, B., \& van de Vliert, E. (1999). Effects of interdependencies in project teams. Journal of Social Psychology, 139, 202-214. 
VandeWalle, D. (1997). Development and validation of a work domain goal orientation instrument. Educational and Psychological Measurement, 57(6), 995-1015.

VandeWalle, D., Brown, S. P., Cron, W. L., \& Slocum J. W. (1999). The influence of goal orientation and self-regulation tactics on sales performance: A longitudinal field test. Journal of Applied Psychology, 84(2), 249-259.

Van Dyne, L., \& Saavedra, R. (1996). A naturalistic minority influence experiment: Effects on divergent thinking, conflict and originality in work-groups. British Journal of Social Psychology, 35(1), 151-168.

Van Hooft, E., \& Noordzij, G. (2009). The effects of goal orientation on job search and reemployment: a field experiment among unemployed job seekers. Journal of Applied Psychology, 94(6), 1581-1590.

Wall, J., \& Callister, R. (1995). Conflict and its management. Journal of Management, 21, 515558.

Wilkens, R., \& London, M. (2006). Relationships between climate, process, and performance in continuous quality improvement groups. Journal of Vocational Behavior, 69(3), 510-523.

Zhou, J., \& George, J.M. (2001). When job dissatisfaction leads to creativity: Encouraging the expression of voice. Academy of Management journal, 44(4), 682-696. 
Figure 1. Conceptual Model

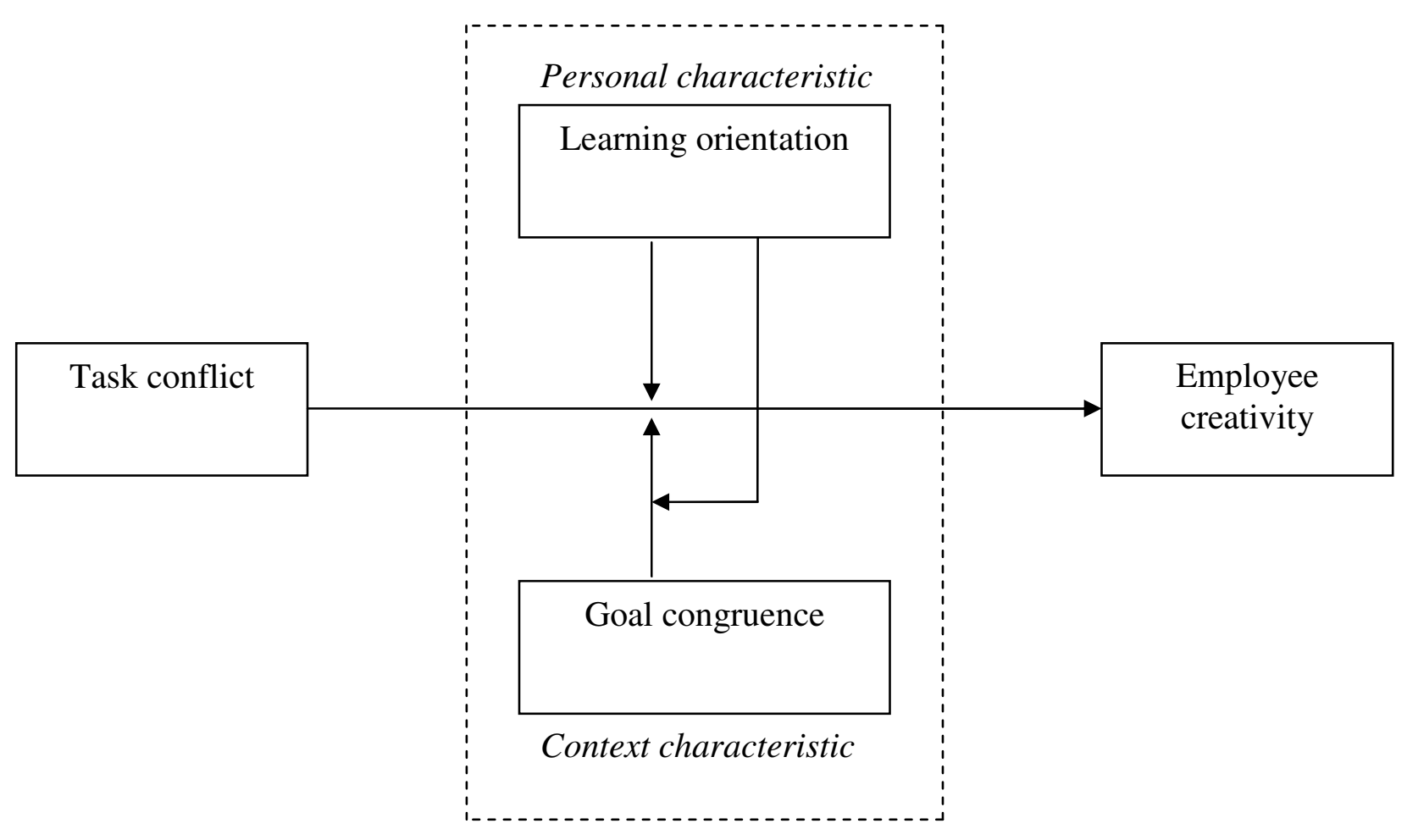


Figure 2. Moderating Effect of Learning Orientation on the Task Conflict-Employee Creativity Relationship

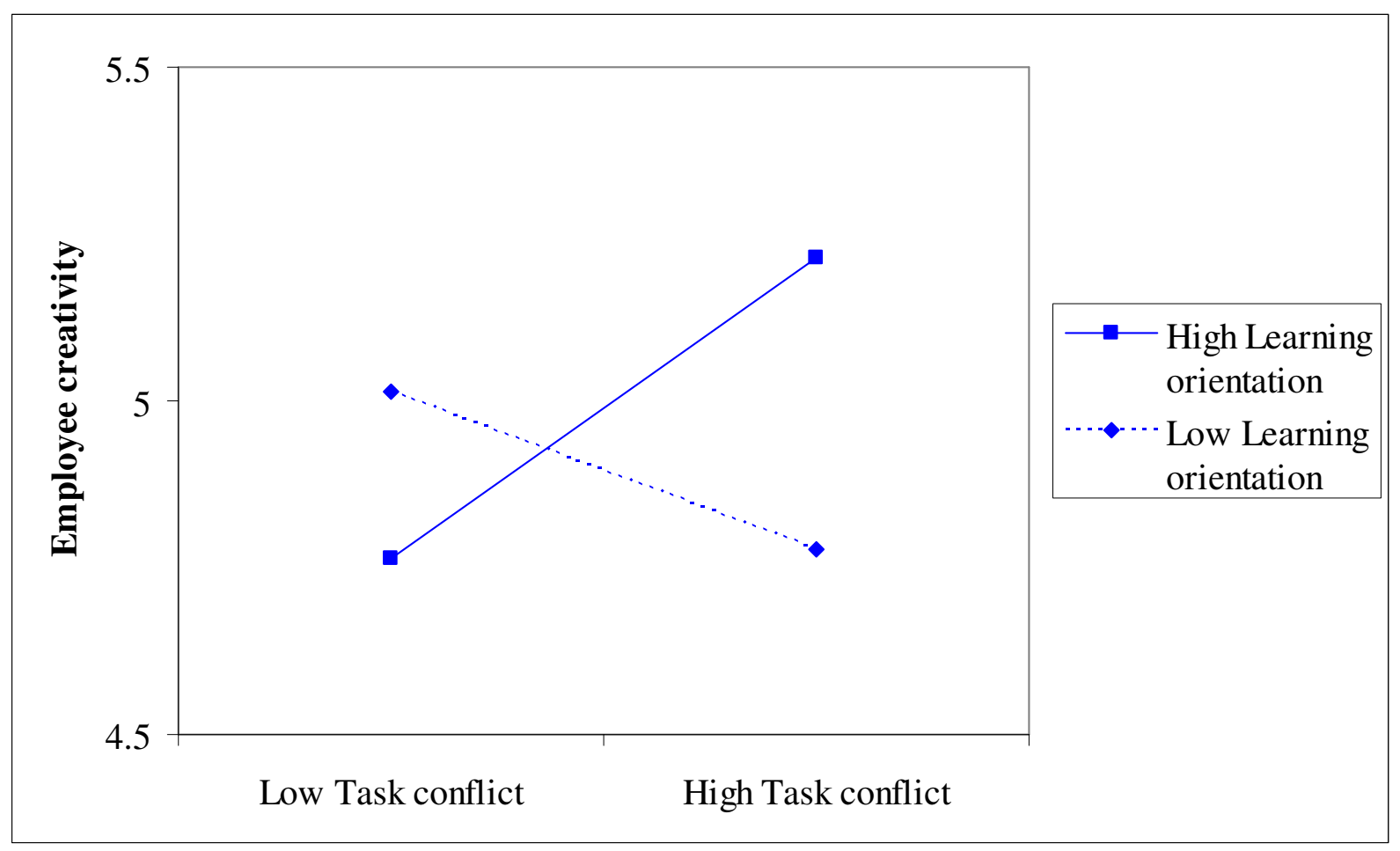


Figure 3. Moderating Effect of Goal Congruence on the Task Conflict-Employee Creativity Relationship

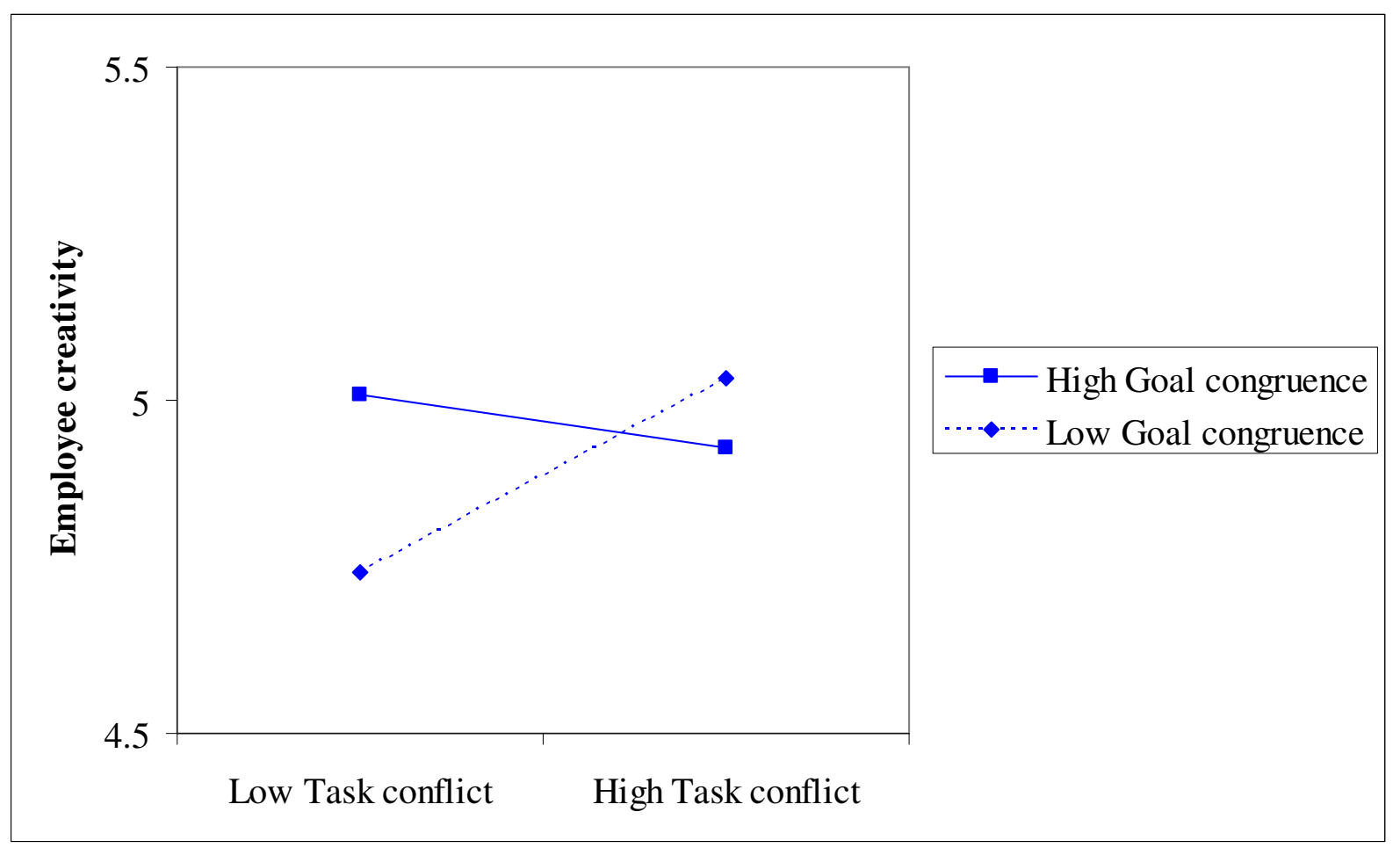


Figure 4. Three-Way Interaction Effect

A: Goal Congruence on the Task Conflict-Employee Creativity Relationship at High Learning Orientation

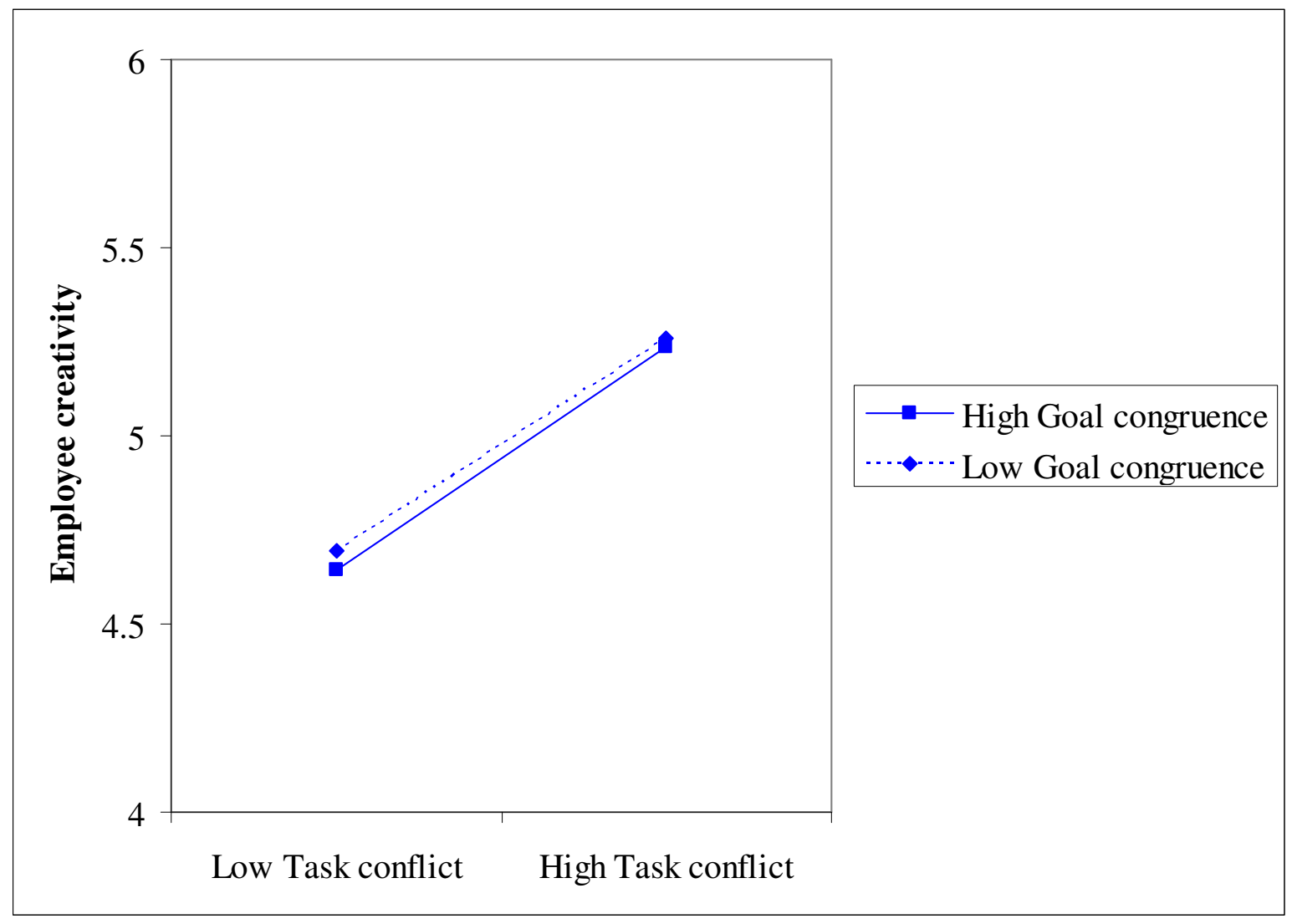


B: Goal Congruence on the Task Conflict-Employee Creativity Relationship at Low Learning Orientation

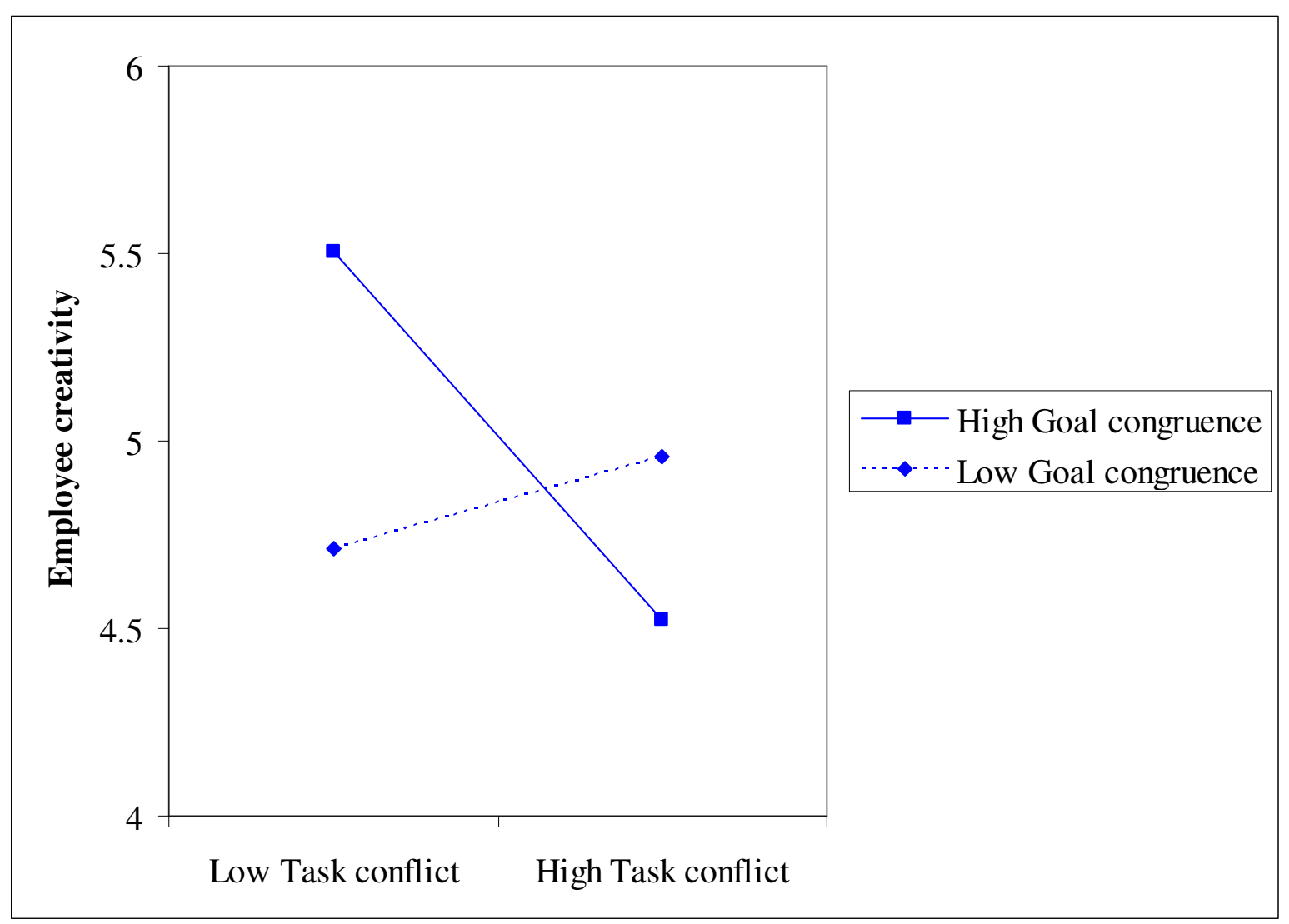


Table 1. Means, Standard Deviations, and Correlations

\begin{tabular}{|c|c|c|c|c|c|c|c|c|c|}
\hline & Mean & SD & 1 & 2 & 3 & 4 & 5 & 6 & 7 \\
\hline 1. Employee creativity & 4.969 & 1.300 & & & & & & & \\
\hline 2. Task conflict & 2.876 & 1.415 & $.098^{* *}$ & & & & & & \\
\hline 3. Learning orientation & 5.210 & 0.776 & .046 & $.297^{* *}$ & & & & & \\
\hline 4. Goal congruence & 5.115 & 1.201 & .070 & $.216^{* *}$ & $.123^{* *}$ & & & & \\
\hline 5. Gender & .219 & .414 & -.016 & -.001 & -.004 & -.034 & & & \\
\hline 6. Age & 33.751 & 7.930 & -.053 & .023 & -.046 & .017 & $-.20^{* *}$ & & \\
\hline 7. Organizational tenure & 3.430 & 1.682 & $.084^{*}$ & .060 & .070 & $.084^{*}$ & $-.01^{* *}$ & $.248^{* *}$ & \\
\hline $\begin{array}{l}\text { 8. Organizational } \\
\text { support }\end{array}$ & 5.580 & 1.510 & .054 & $.290^{* *}$ & $.151^{* *}$ & $.248^{* *}$ & .023 & .030 & -.048 \\
\hline
\end{tabular}

Note: $\mathrm{N}=707$.

$* * p<.01 ; * p<.05$. 
Table 2. Regression Results (Dependent Variable: Employee Creativity)

\begin{tabular}{|c|c|c|c|c|c|}
\hline & Model 1 & Model 2 & Model 3 & Model 4 & Model 5 \\
\hline Gender & -.076 & -.075 & -.071 & -.092 & -.080 \\
\hline Age & $-.014^{*}$ & $-.014^{*}$ & $-.014^{*}$ & $-.012^{+}$ & $-.012^{+}$ \\
\hline Organizational tenure & $.082^{* *}$ & $.077^{*}$ & $.074^{*}$ & $.067^{*}$ & $.070^{*}$ \\
\hline Organizational support & $.054^{+}$ & .033 & .025 & .041 & .036 \\
\hline H1: Task conflict & & $.107^{*}$ & $.098^{+}$ & .053 & .037 \\
\hline Learning orientation & & & .007 & .046 & .022 \\
\hline Goal congruence & & & .042 & .041 & .029 \\
\hline $\mathrm{H} 2$ : Task conflict $\times$ Learning orientation & & & & $.172^{* *}$ & $.215^{* *}$ \\
\hline H3: Task conflict $\times$ Goal congruence & & & & $-.093^{* *}$ & $-.089^{* *}$ \\
\hline Learning orientation $\times$ Goal congruence & & & & & -.058 \\
\hline $\begin{array}{l}\text { H4: Task conflict } \times \text { Goal congruence } \times \\
\text { Learning orientation }\end{array}$ & & & & & $.119^{*}$ \\
\hline $\begin{array}{l}\text { F-value } \\
\mathrm{R}^{2} \\
\mathrm{R}^{2} \text { change }\end{array}$ & $\begin{array}{c}3.022^{*} \\
.017\end{array}$ & $\begin{array}{c}3.320^{* * *} \\
.023 \\
.006^{*} \\
\end{array}$ & $\begin{array}{c}2.507^{*} \\
.025 \\
.002 \\
\end{array}$ & $\begin{array}{c}4.011^{\text {*** }} \\
.050^{* * *} \\
.025^{* * *}\end{array}$ & $\begin{array}{c}3.881^{\text {*** }} \\
.058 \\
.008^{+}\end{array}$ \\
\hline
\end{tabular}

Notes: $\mathrm{N}=707$; unstandardized coefficients (two-tailed $p$-values).

$* * * p<.001 ; * * p<.01 ; * p<.05 ;{ }^{+} p<.10$. 